\title{
Пульмонологічна реабілітація при ХОЗЛ
}

\author{
Масік Н. П. \\ Вінницький національний медичний університет імені М. І. Пирогова, м. Вінниця, Україна
}

Актуальність. Згідно 3 рекомендаціями GOLD, головними цілями пульмонологічної реабілітації є зменшення симптомів, поліпшення якості життя і підвищення фізичної та емоційної участі пацієнта у повсякденному житті. Повноцінна реабілітаційна програма включає модифікацію способу життя, регулярні фізичні навантаження, заходи з корекції маси тіла, психологічну підтримку.

Мета дослідження: оцінити ефективність реабілітаційних заходів у хворих на ХОЗЛ.

Матеріали та методи. Обстежено 182 хворих на ХОЗЛ ІІІ стадії середнього віку $61,55 \pm 13,57$ років. Для кожного хворого підбирали індивідуальну програму реабілітації, з урахуванням специфічних фізіологічних та психопатологічних порушень, викликаних основним та супутніми захворюваннями. Застосовували заняття лікувальною фізкультурою та дихальною гімнастикою за методикою регламентованого управління диханням, що забезпечує відновлення нормального стереотипу дихання зі зменшенням обмеження повітряного потоку i попередженням розвитку ускладнень. Інтенсивність фізичних навантажень при цьому залежала від можливостей пацієнта. Переносимість фізичного навантаження оцінювалась хворими самостійно за допомогою тесту з 6-хвилинною ходою. Оцінку ефективності проводили через 10 тижнів реабілітаційного лікування.

Результати дослідження. Встановлено зниження показника фізичного благополуччя якості життя у 75,27 \% хворих, з них у 30,77\% молодих і $71,43 \%$ старечого віку. Використання методики регламентованого дихання у поєднанні з дозованим фізичним навантаженням у 85,71\% випадків вірогідно знижує задишку при фізичному навантаженні, сприяє позитивній динаміці клінічних симптомів, зокрема зменшенню респіраторних симптомів, покращенню показників зовнішнього дихання і зниженню потреби в медикаментозних препаратах. Показник фізичного статусу покращувався у половини хворих на ХОЗЛ. Дещо гірший показник відзначався серед людей старечого віку; цей показник залишався зниженим у $62,09 \%$ осіб.

Отже, методика регламентованого дихання із дозованим фізичним навантаженням адаптує хворих до зростаючого фізичного навантаження, сприяючи збереженню працездатності і покращенню якості життя.

Висновки. Інтегрована в щоденне лікування пульмонологічна реабілітація здатна оптимізувати функціональний статус і зменшити вартість лікування за рахунок стабілізації або зменшення проявів хвороби. 